\title{
Physicochemical regularities of a high-voltage electroporcelain formation with a sintering temperature of $1200^{\circ} \mathrm{C}$
}

\author{
K.B.Bohdanova \\ National Technical University "Kharkiv Polytechnic Institute", \\ 2 Kirpicheva Str., 61002 Kharkiv, Ukraine
}

Received May 4, 2018

The composition and technological parameters of manufacturing low-temperature electroporcelain with complex of high electrophysical and mechanical properties have been developed. With the use of differential thermal, X-ray phase, IR spectroscopic and electron microscopic methods of analysis, physicochemical regularities in the formation of electrical porcelain at $1200^{\circ} \mathrm{C}$ have been established. It is shown that high dielectric and mechanical characteristics of low-temperature porcelain $\left(\rho_{V}=4.1 \cdot 10^{14} \mathrm{Ohm} \cdot \mathrm{cm} ; E=(29\right.$ 30) $\mathrm{kV} \cdot \mathrm{mm}^{-1} ; \operatorname{tg} \delta \cdot 10^{3}=12.11 ; \sigma_{r}=31 \mathrm{MPa}$ ) are provided by activating the sintering with the participation of a modified feldspar melt and intensive formation of the mullite phase in the form of microfibers with a predominant size of $\sim 0.007 \div 8 \mu \mathrm{m}$ with the addition of complex mineralizer additives (12 wt. \% pyrophyllite and $0.3 \mathrm{wt} \%$ titanium dioxide).

Keywords: low-temperature electrical porcelain, dielectric strength, electrical resistance, mineralizer, phase formation, mullite.

Разработаны составы масс и технологические параметры ускоренного низкотемпературного обжига высоковольтных фарфоровых изоляторов. С использованием дифференциально-термического, рентгенофазового, ИК-спектроскопического и әлектронно-микроскопического методов анализа установлены физико-химические закономерности формирования электрофарфора при температуре $1200^{\circ} \mathrm{C}$. Показано, что высокие диэлектрические и механические характеристики низкотемпературного фарфора $\left(\rho_{V}=\right.$ $4.1 \cdot 10^{14}$ Ом.см; $E_{n p}=29-30 \mathrm{kB} \cdot \mathrm{M} \mathrm{M}^{-1} ; \operatorname{tg} \delta \cdot 10^{3}=12.11 ; \sigma_{\text {разр }}=31 \mathrm{MПа)} \mathrm{обеспечиваются}$ за счет активации спекания при участии модифицированного полевошпатового расплава и интенсивного образования муллитовой фазы в виде микроволокон с преобладающим размером $\sim 0,007 \div 8$ мкм при введении добавок комплексного минерализатора (12 масс. \% пирофиллита и 0,3 масс. \% диоксида титана).

Фізико-хімічні закономірності формування високовольтного електропорцеляну з температурою спікання $1200^{\circ} \mathrm{C}$. К.Б.Богданова.

Розроблено склади мас і технологічні параметри прискореного низькотемпературного випалу високовольтних фарфорових ізоляторів. 3 використанням диференційнотермічного, рентгенофазового, ІЧ-спектроскопічного і електронно-мікроскопічного методів аналізу встановлено фізико-хімічні закономірності формування електрофарфору за температури $1200^{\circ} \mathrm{C}$. Показано, що високі діелектричні і механічні характеристики низькотемпературного фарфору $\left(\rho_{V}=4.1 \cdot 10^{14}\right.$ Ом.см; $E_{n p}=29-30 \mathrm{\kappa B} \cdot \mathrm{m} \mathrm{M}^{-1} ; \operatorname{tg} \delta \cdot 10^{3}=$ $12.11 ; \sigma_{\text {разр }}=31$ МПа) забезпечуються шляхом спікання за участі модифікованого польовошпатового розплаву та інтенсивного утворення мулітової фази у вигляді мікрово-

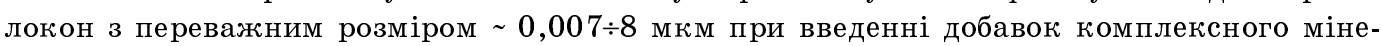
ралізатора (12 мас. \% пірофіліту і 0,3 мас. \% діоксиду титану). 


\section{Introduction}

Porcelain remains an irreplaceable insulating material due to its high dielectric properties, resistance to some aggressive factors of the environment (sun radiation, high wettity, chemical emissions of factories) and as a consequence, long term of effective exploitation (more than 25 years). Priority direction of the development of electrical porcelain technology is the reduction of fuel costs and the expansion of the raw material base of production, while maintaining a high level of performance properties of products.

The complex solution of the problem of energy saving and in the production of porcelain insulators is related to reducing of duration and a decreasing of sintering temperature using alternative raw materials. Successful implementation of this direction is possible under the condition of intensification of the sintering and phase-formation processes of porcelain during low-temperature firing (up to $1200^{\circ} \mathrm{C}$ ), incl. methods of chemical modification.

The purpose of this research is developing a composition of low-temperature electrical porcelain and studying of the processes of structure formation and phase composition, as factors which determine the functionality and reliability of porcelain insulators during exploitation.

\section{Experimental}

The study used the following raw materials: Vesco-Extra clay, kaolin, quartz sand, feldspar material, dolomite, pyrophyllite rocks (materials from Ukraine). Considering the positive experience of the feldspar materials and pyrophyllites using [1-8] in porcelain technology, these raw materials were used as a melting point and an activator of the mullite phase formation under conditions of low-temperature electrical porcelain synthesis. As mineralizing additives, boron oxide $\mathrm{B}_{2} \mathrm{O}_{3}$ - boric acid, $\mathrm{Li}_{2} \mathrm{O}$ - with lithium carbonate, $\mathrm{CuO}, \mathrm{SnO}_{2}, \mathrm{TiO}_{2}-$ chemical reagents of grade "pure" was additionally introduced.

During experiments gamma-spectrometric (CEG-001 "AKP-C"), differential-thermal (NETZSCH STA 409 PC/PG), X-ray phase (DRON-3M), infrared spectroscopic Perkin Elmer Spectrum One) and electron microscopic REMMA-101A) methods of analysis were used. Dielectric and mechanical properties of electrical porcelain samples were determined in special laboratories of the High Voltage Research Institute (Slavyansk, Ukraine); Higher School of Wismar (Wismar, Germany); "Kharkiv Electronica" (Kharkiv, Ukraine).

\section{Results and discussion}

The development of the low-temperature porcelain masses was carried out using the simplex-lattice planning method (Fig. 1). The water absorption (as a characteristic of the degree of sintering of ceramics), the intensity of the main mullite reflex on the X-ray patterns of porcelain samples (as a criterion for completing the mullite formation process) and their general shrinkage were chosen as optimization criteria. Analysis of properties, which characterize the degree of porcelain sintering, allowed to determine the optimal ratio of raw components (mass content, \%): clay - 32, kaolin -8 , feldspar - 33, quartz sand -15 , pyrophyllite -12 , dolomite -2 (over $100 \%$ ). This composition provides the maximum level of sintering (water absorption $W-0.06 \%$ ) and minimal level of shrinkage $(L \leq 14 \%)$ at the firing temperature $1200^{\circ} \mathrm{C}$. However due to insufficient of mullite formation process, the obtained material does not reach the level of mechanical and electrophysical properties, required for porcelain insulators $(\sigma \geq 60 \mathrm{MPa}$, $\sigma_{u t c} \geq 30 \mathrm{MPa}, E \geq 25 \mathrm{kV} \cdot \mathrm{mm}^{-1}$ according to GOST 20419-83).

For the intensification of mullite formation, the developed mass was modified by adding mineralizing additives. The following requirements were used, when choosing mineralizers: efficiency of mineralizing (from the standpoint of mullite formation), lack of negative influence on electrophysical properties and probability of high-temperature deformation of products during sintering, high dispersity, availability. During the investigation, the effectivity of mineralizers have been studied. According to [9-11]:

- $\mathrm{TiO}_{2}-$ mullite formation in the form of solid solutions;

- $\mathrm{Li}_{2} \mathrm{O}, \mathrm{B}_{2} \mathrm{O}_{3}$ - decrease of the melt formation temperature and acceleration of recrystallization of the mullite through the melt;

- $\mathrm{CuO}, \mathrm{SnO}_{2}-$ influence on reactivity ability of the melt and coordination complex of alumina $\left([\mathrm{Al}]^{4+} \rightarrow[\mathrm{Al}]^{6+}\right)$.

The influence mineralizing effect of the additives was evaluated from the intensity of reflections of crystal phases on the X-ray patterns of samples (Table 1). As it can be seen from presented data, the effect of min- 
K.B.Bohdanova / Physicochemical regularities of ...

Table. Dependence of intensity of reflexes quartz and mullite from mineralizing additions

\begin{tabular}{|c|c|c|c|c||}
\hline \multirow{2}{*}{$\begin{array}{c}\text { Content of addi- } \\
\text { tive, } \%\end{array}$} & \multicolumn{4}{|c||}{ Intensity of reflexes of crystal phases $I, \mathrm{~mm}$} \\
\cline { 2 - 5 } & \multicolumn{2}{|c|}{$3 \mathrm{Al}_{2} \mathrm{O}_{3} \cdot 2 \mathrm{SiO}_{2}$} & \multicolumn{2}{|c||}{$\mathrm{SiO}_{2}$} \\
\cline { 2 - 5 } & $d_{95}=0.3424 \mathrm{~nm}$ & $\Delta I_{\text {mullite } \%}$ & $d_{30}=0.4267 \mathrm{~nm}$ & $\Delta I_{\text {quartz }}, \%$ \\
\hline Without additives & $80 \pm 0.5$ & - & $152 \pm 0.5$ & - \\
$0.3 \% \mathrm{~B}_{2} \mathrm{O}_{3}$ & $85 \pm 0.5$ & +6.25 & $136 \pm 0.5$ & -10.53 \\
$0.3 \% \mathrm{CuO}$ & $89 \pm 0.5$ & +11.25 & $140 \pm 0.5$ & -7.89 \\
$0.3 \% \mathrm{Li}_{2} \mathrm{O}$ & $87 \pm 0.5$ & +8.75 & $145 \pm 0.5$ & -4.61 \\
$0.3 \% \mathrm{TiO}_{2}$ & $90 \pm 0.5$ & +12.50 & $150 \pm 0.5$ & -1.32 \\
$0.3 \% \mathrm{SnO}_{2}$ & $88 \pm 0.5$ & +10.00 & $131 \pm 0.5$ & -13.82 \\
\hline
\end{tabular}

$*$ mass content of additive, \% (over $100 \%$ )

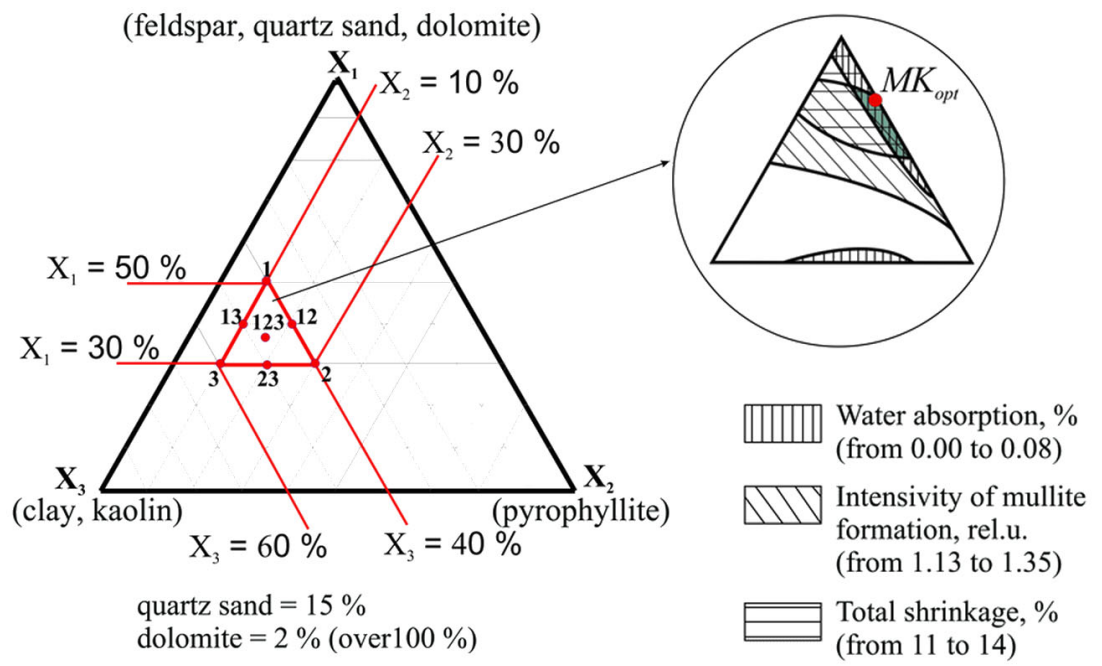

Fig. 1. Simplex-lattice planning method of the low-temperature porcelain masses.

eralizing additives consists not only in increasing of the intensity of mullite reflexes $\left(+\Delta I_{\text {mullite }}\right)$, but also in decreasing of quartz reflexes intensivity $\left(-\Delta_{\text {quart } z}\right)$, which indirectly points to its dissolution. It has been determined that $\mathrm{TiO}_{2}, \mathrm{CuO}$ and $\mathrm{SnO}_{2}$ are the most effective additives for accelerating the "ripening" of porcelain.

Additions of $\mathrm{CuO}$ and $\mathrm{SnO}_{2}$ increase the solubility of the quartz relicts but are less effective from the aspect of enhancing porcelain mullitization. The addition of $\mathrm{TiO}_{2}$ intensifies the mullite formation, practically does not promotes dissolution of quartz in the melt, which in turn, along with mullite, ensures the strength of the product, and does not adversely affect the characteristics of sintering of the mass, such as $\mathrm{CuO}$ and $\mathrm{Li}_{2} \mathrm{O}$, which shorten the porcelain sintered state interval. On the basis of the foregoing, as an optimum min- eralizing additive for the low-temperature porcelain sintering, 0.3 mass. $\%$ of $\mathrm{TiO}_{2}$ (over $100 \%$ on a dry substance) have been added to the mass composition.

Studies of samples, which were obtained at $1200^{\circ} \mathrm{C}$ showed that the developed low-porcelain is characterized by complex of high electro-physical and physico-mechanical properties that determine quality of high-voltage porcelain insulators, according to current GOST 20419-83: specific volume resistivity ( $f=$ $50 \mathrm{~Hz}) ; \quad \rho_{V}=4.1 \cdot 10^{14} \mathrm{Ohm} \cdot \mathrm{cm} ; \quad$ electric strength (at $f=50 \mathrm{~Hz}) E_{\text {str }}=29-30 \mathrm{kV} \cdot \mathrm{mm}^{-}$ 1; tangent of the dielectric loss angle (at $f=$ $50 \mathrm{~Hz}) \operatorname{tg} \delta \cdot 10^{3}=12.11$; water absorption $W$ $=0 \%$; bending strength $\sigma_{\text {bend }}=63 \mathrm{MPa}$; tensile strength $\sigma_{\text {tensile }}=31 \mathrm{MPa}$; apparent density $\rho_{\text {apparent }}=2.86 \mathrm{~g} / \mathrm{cm}^{3}$; linear coefficient of thermal expansion $\alpha_{20-100^{\circ} \mathrm{C}}=$ 


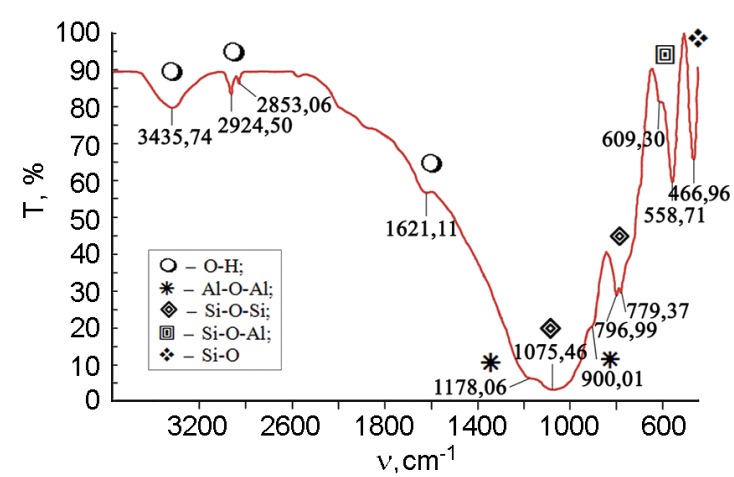

Fig. 2. IR-spectra of the low-temperature porcelan sample 13 .

$4.9 \mathrm{deg}^{-1}$, open porosity $\varphi-$ no staining in the fuchsine solution.

The results of $\mathrm{X}$-ray diffraction analysis of the material indicate that the crystalline constituent of the developed material is mainly represented by mullite $(d / n=0.540$; $0.378 ; 0.3427 ; 0.3386 ; 0.287 ; 0.2696$; $0.2546 \mathrm{~nm})$ and residual quartz $(d / n=$ $0.4266 ; 0.3343)$; cristobalite was not identified. Figure 2 shows an IR-spectrum of the low-temperature porcelain sample. The presence of the mullite is indicated by bands at 1178 and $900 \mathrm{~cm}^{-1}$, which are characterized by great diffusion, since groups $\mathrm{AlO}_{4}$ and $\mathrm{SiO}_{4}$ alternate disorderly. A strong doublet band with maxima at 797 and $779 \mathrm{~cm}^{-1}$ indicates that the crystalline quartz is presented by $\alpha$-form, since its other modifications give only one band in this region.

According to results of DTA (Fig. 3), the process of formation of low-temperature electrical porcelain is accompanied by two endothermal effects (with maxima at $560^{\circ} \mathrm{C}$ and $880^{\circ} \mathrm{C}$ ), which corresponds to the destruction of kaolinite and pyrophyllite crystal lattice as a result of the removal of chemically bounded moisture, for which the mass loss was $2.5 \%$. The further insignificant increase in mass $(\sim 0.5 \%)$ can be explained by the formation of the mullite phase which passes from both components, such illustrated the presence of two exothermic effects with maxima at $980^{\circ} \mathrm{C}$ and $1150^{\circ} \mathrm{C}$. Thus, the presence of two alumino-silicate materials in porcelain composition, allows to intensify the formation of mullite phase in the porcelain, under conditions of low-temperature sintering.

The result of differential thermal and dilatometric analyses [12] formed the basis for development of the sintering regime for lowtemperature electrical porcelain, which provides heating to $800^{\circ} \mathrm{C}$ with speed $\sim 65-$ $67^{\circ} \mathrm{C} / \mathrm{h}$, heating with speed $\sim-23^{\circ} \mathrm{C} / \mathrm{h}$ in the

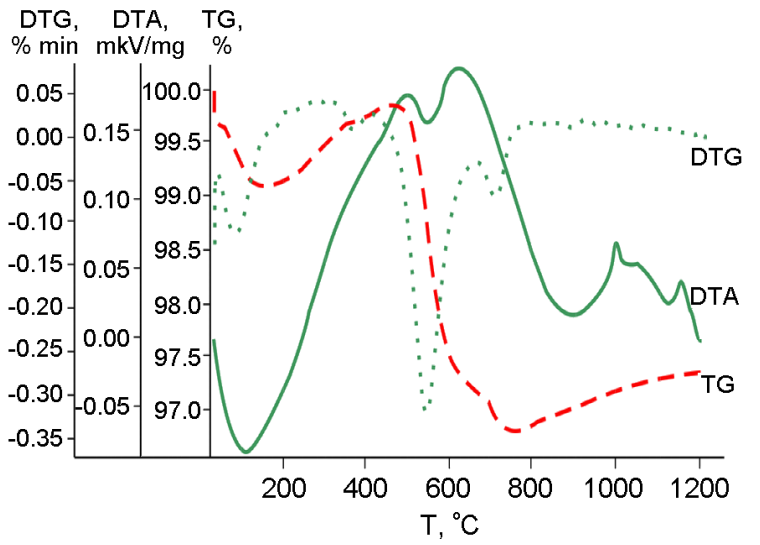

Fig. 3. Results of thermogravimetric analysis of low-temperature electrical porcelain.

temperature range $800-1000^{\circ} \mathrm{C}$, with speed $40^{\circ} \mathrm{C} / \mathrm{h}$ in the range $1000-1200^{\circ} \mathrm{C}$, isothermal exposure at $1200^{\circ} \mathrm{C}$ during two hours, rapid temperature decrease to $1000^{\circ} \mathrm{C}$ with the speed $\sim 115-117^{\circ} \mathrm{C} / \mathrm{h}$, in the range $1000-700^{\circ} \mathrm{C}$ with the speed $\sim 30^{\circ} \mathrm{C} / \mathrm{h}$ and at the section $700-$ $500^{\circ} \mathrm{C}$ - with the speed $\sim 15^{\circ} \mathrm{C} / \mathrm{h}$.

As it known, the reliability of the insulator during long-term operation is determined, first of all, by homogeneity of the material structure. Studying of the morphology of low-temperature was carried out according to the petrographic and electronmicroscopic studies result. Characteristics of the porcelain, which was obtained at $1200^{\circ} \mathrm{C}$ from the developed mass (sample "NFT") and high-voltage porcelain of industrial production (sample "VZF"), which was sintered at high-temperature $\left(1350^{\circ} \mathrm{C}\right)$, have been analyzed.

Petrographic analysis of the factorymade porcelain sample "VZF" showed that its fragment is characterized by a rough micro relievo and a large-block structure. The most part of the mass of the material is represented by an isotropic glass-mullite components of light-brown color with average of light refraction $N_{c} \sim 1.514 \div 1.524$. Quartz $(\sim 23 \div 25 \%)$ is present as isometric and elongated grains of irregular shape with an average size $10 \div 20 \mu \mathrm{m}$. The part of grains reaches $\sim 60 \mu \mathrm{m}$. A thin border of fusion with a width of up to $3 \mu \mathrm{m}$ is observed around grains. Grains of residual feldspar $(\sim 27 \div 30 \%)$ are noticeable. In areas of feldspar grains mullite is formed in the form of individual thin needles up to $10 \mu \mathrm{m}$ in size. Closed pores of round and oval share $(\sim 8 \div 12 \%)$, which formed due to degassing of the raw materials and releas- 


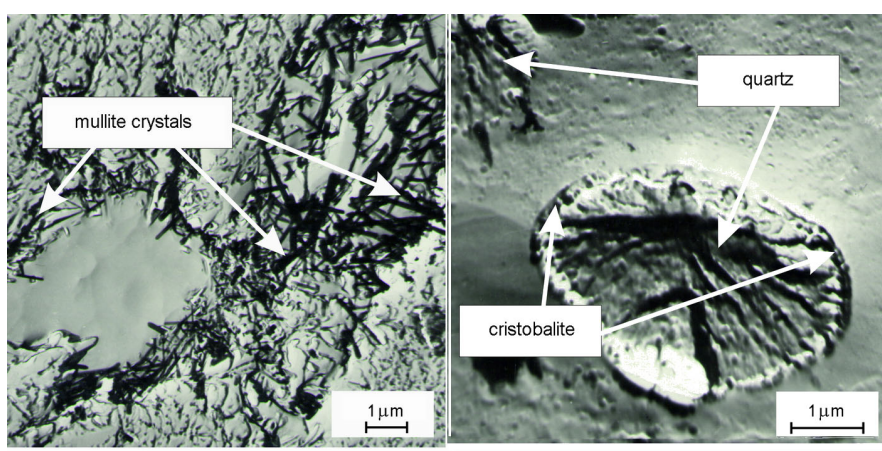

a)

b)

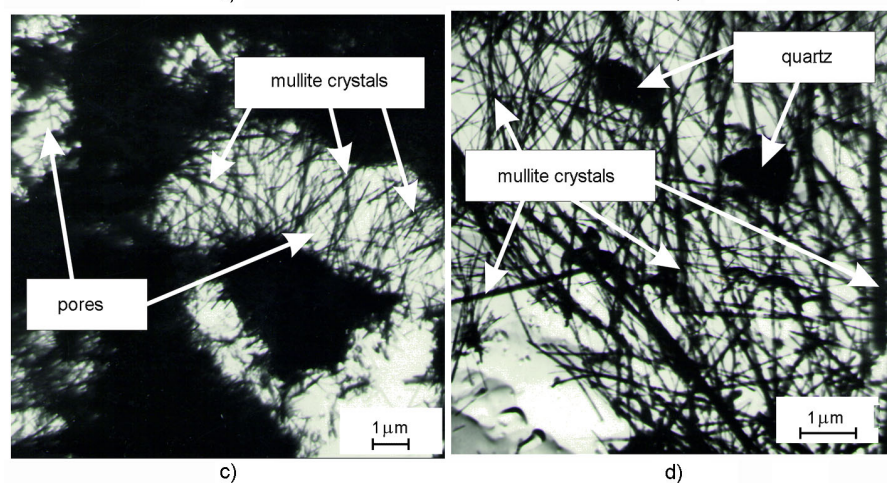

Fig. 4.Microstructure of the samples: (a-b) factory porcelain "VZF"; (c-d) low-temperature porcelain "NTF".

ing of the $\mathrm{OH}$ hydroxyl group during the decomposition and sintering process of the clay materials are observed. Pores with an average size of $4 \div 6 \mu \mathrm{m}$ are distributed relatively evenly and only occasionally form chains and small clusters with a maximum size of $\sim 12 \mu \mathrm{m}$. This indicated an insufficient degree of porcelain ripening.

The break of the sample of low-temperature porcelain "NFT" is characterized by soft micro-relief, a small blockiness with a thin interblock boundary. The structure is characterized by greater homogeneity of the glassmullite phase, without isolated sections of feldspar glass and inclusions of large quartz remnants. Main mass is represented by colorless transparent isotropic glass mullite aggregates $(\sim 75 \%)$ with a refractive index of $N_{C} \sim 1.524 \div 1.530$.

The size of residual quartz grains does not exceed $10 \mu \mathrm{m}$. Around grains, edges of reflow up to $2 \mu \mathrm{m}$ are marked up. Remnants of feldspar are not distinguishable, on their places in the field of feldspar glass, mullite needles up to $2 \cdot(10 \div 12) \mu \mathrm{m}$ in the size are formed, that forms a felt-like weave. The average size of single pores is $4 \div 10 \mu \mathrm{m}$.

Results of studying of the structure of porcelain samples using bitmapped electron microscopy clearly reflects the features of their structure. Microphotographs clear show crystalline and amorphous areas, that correspond to mullite, quartz and glass phase, which allows to estimate the ratio of the material in crystalline and glass phase and confirms quantitative data of petrographical analysis. In fractographic photography of break of the sample "VZF", a rough microrelief and a large-block structure are observed. To study the morphology of the crystalline phase on the glassmullite component of porcelain, the samples were exposed to chemical etching in $10 \% \mathrm{HF}$ solution. This allowed to determine that mullite crystals, which were detected after removal of the glass phase from the glass mullite aggregate are represented by prismatic and acicular shapes (Fig. 4a) with a size of $0.06 \times 0.8 \mu \mathrm{m}^{2}$ to $0.25 \times 4.0 \mu \mathrm{m}$. There are isometric grains of quartz in the material, the smallest of which exceed $2.5 \mu \mathrm{m}$. Fig. 4b illustrates the changes in quartz crystals as a result of firing: the grain during the transformation show cracks, along which vitrification develops. In reaction border, the initial stage of the formation of cristobalite as a smallest nucleus is observed.

Thus, the structure of the "VZF" sample is characterized by presence of quartz grains and residual of clay minerals, interspersed with the main mass, consisting a 
glass phase, permeated by crystals of primary and secondary mullite.

The crystalline phase of the "NFT" sample is represented by mullite $(\sim 33 \%)$, in the form of long fiber-like crystals with average size $\sim 0.007 \cdot 8.0 \mu \mathrm{m}$, forming clusters in the form of dense felt. Needle-shaped crystals of mullite germinate in pores (Fig. 4c), which also helps to strengthen the material. Due to partial melting of quartz grains in feldspar melt, their sizes do not exceed $1.0 \times 1.0 \mu \mathrm{m}^{2}$. The picture shows mullite, that join together small residual quartz grains $(\sim 1 \mu \mathrm{m})$, which helps to bound them into the strength monolith (Fig. 4d). Quartz crystals and long curved crystals of secondary mullite evenly fill the glass phase and form strong felt-like structure of the material. As it can be seen from represented pictures of microstructure in low temperature porcelain there are no cristobalite neoplasms, which agrees with XRD and DTA results.

Thus, it has been established that the developed low-temperature electrical porcelain differs by more homogenous finegrained structure, that is represented by glassmullite phase which has small isometric grains of quartz that are significantly degenerated due to fusion. Despite a significant reduction in a sintering temperature $\left(1200^{\circ} \mathrm{C}\right.$ instead of $1350^{\circ} \mathrm{C}$, that used in technology of electroporcelain), the presence of a complex flux, consisting of feldspar and dolomite, ensures a formation of significant amount of highly active melt, which creates favorable conditions for the dissolution of quartz grains and the development of secondary mullite in the presence of mineralizing components (pyrophyllite and $\mathrm{TiO}_{2}$ ).

This ensures an even distribution of the fine dispersed components of low-temperature porcelain, which explains the high electrical strength of the resulting material. The homogeneous structure of the developed material, as well as the optimal phase composition (fiber-like mullite and glass phase in proportion $1.3: 1.0$ ) helps to create more dense material and provides a high index of flexural strength and tear resistance.

\section{Conclusions}

As the result of carried experiments the composition and technological parameters of low-temperature electrical porcelain have been developed. According to the results of experiments in special laboratories, the lowtemperature materials, which was developed, suits the requirements of GOST 20419-83 for high voltage silica porcelain. Peculiar qualities of the low-temperature formation process (at $1200^{\circ} \mathrm{C}$ ) have been developed, which are in active sintering of the material with modified feldspar melt and intensive mullite phase formation with complex mineralization (12 wt. \% pyrophyllite and 0.3 wt. $\%$ titanium dioxide). The composition is recommended for developing of high-voltage insulators with voltage up to $10 \mathrm{kV}$.

\section{References}

1. I.V.Synyakovskaya, V.V.Zajkov, Pyrophyllite Raw Materials of the Kul-Yurt-Tau Deposit, Uro RAN, Ekaterinburg (2010).

2. V.S.Bakunov, A.R.Murzakova, R.U.Shajahmetov et al., Steklo i Keramika, 12, 23 (2011).

3. T.K.Mukhopadhyay, S.Ghatak, H.S.Maiti, Ceram. Int., 35, 1493 (2009).

4. E.S.Abdrakhimova, V.Z.Abdrakhimov, $Z h$. Neorgan. Khimii, 52, 345 (2007).

5. E.Y.Fedorenko, M.I.Ryshchenko, E.B.Daineko et al., Glass Ceram., 70, 1 (2013).

6. O.E.Baluta, Ja.V.Cimbaljuk, in: Book Abstr. Inter-branch Sci.-pract. Meet. on Development of Ceramic Production, Kyiv, Ukraine (2007), p.39.

7. M.I.Ryshchenko, E.Ju.Fedorenko, M.A.Chirkina, Steklo i Keramika, 11, 26 (2009).

8. E.B.Daineko, A.M.Juminov, N.Ju.Glushhenko et al., in: Book 20th Sci. Youth School on Metallogeny of the Ancient and Modern Oceans, Miass, Russia (2014), p.275.

9. G.N.Maslennikova, Ju.T.Platov, Steklo $i$ Keramika, 2, 19 (1998).

10. V.I.Vereshhagin, Steklo $i$ Keramika, 12, 6 (2002).

11. T.V.Vakalova, A.A.Reshetova, Ogneupory $i$ Tekhn. Keramika, 7-8, 74 (2009).

12. E.B.Daineko, E.Yu.Fedorenko, M.I.Ryshchenko, Ekologiya i Promyishlennost', 4, 78 (2016). 